\title{
Taksiran Zakat Pertanian Dalam Kitab Sabil Al-Muhtadin
}

\section{Agriculture-Product Zakat Assessment According To The Sabil Al-Muhtadin Scripture}

\author{
Zahri Hamat (Pengarang Penghubung) \\ Pusat Pengajian Sains Kemasyarakatan \\ Universiti Sains Malaysia, 11800 Pulau Pinang, Malaysia \\ Tel. +604-653 2660,+6019-472 7353 E-mel: zahri@usm.my \\ Mohd Shukri Hanapi \\ Pusat Kajian Pengurusan Pembangunan Islam (ISDEV) \\ Universiti Sains Malaysia, 11800 Pulau Pinang, Malaysia \\ Tel. 04-653 2665, +6019-450 7576 E-mel: hshukri@usm.my
}

\begin{abstract}
Abstrak
Kertas ini bertujuan untuk mengenal pasti pengaruh faktor semasa ketika membuat taksiran zakat hasil pertanian yang dibahaskan oleh Syeikh Muhammad Arsyad al-Banjari dalam kitab Sabil al-Muhtadin. Kitab Sabil al-Muhtadin adalah tulisan Syeikh Muhammad Arsyad alBanjari yang termasyhur. Persoalannya, apakah beliau telah mengambil kira keadaan semasa dan keperluan setempat pada masa itu semasa kitab Sabil al-Muhtadin ditulis? Bagaimanakah pula kaedah yang dipakai dalam tulisan beliau itu boleh diambil manfaat pada masa kini? Kertas ini dibahagikan kepada tiga bahagian. Pertama akan menyorot secara ringkas biodata Syeikh Muhammad Arsyad al-Banjari sebagai latar belakang. Kedua akan membahaskan taksiran zakat hasil pertanian dalam kitab Sabil alMuhtadin. Ketiga akan menganalisis kaedah taksiran zakat hasil pertanian dalam Sabil al-Muhtadin khususnya dalam menentukan kadar zakat pertanian. Akan dihujahkan bahawa walaupun perbahasan Syeikh Muhammad Arsyad al-Banjari terhadap taksiran zakat hasil pertanian dalam kitab Sabil al-Muhtadin telah mengambil kira keadaan semasa pada masa itu, namun akibat keperluan semasa pada masa ini, maka timbul penambahbaikan dalam taksiran zakat hasil pertanian adalh diperlukan khususnya di Malaysia.
\end{abstract}

Katakunci: pengagihan zakat, asnaf fakir dan miskin, keadaan semasa dan setempat

\begin{abstract}
This paper intends to identify the influence of the existing factors when assessing agricultureproduct zakat as discussed by Syeikh Muhammad Arsyad al-Banjari in the Sabil alMuhtadin scripture. The Sabil al-Muhtadin scripture was written by the famous Syeikh Muhammad Arsyad al-Banjari. The question is, had the writer taken into consideration the existing situation and needs of the referred location at that moment in time when the Sabil al-Muhtadin scripture was written? How could the method mentioned by the writer in his work be of benefit at the present moment? This paper is divided into three sections. The first section would briefly review the bio-data of Syeikh Muhammad Arsyad al-Banjari as the background of the paper. The second section would debate the assessment of agriculture-product zakat found in the Sabil al-Muhtadin scripture. Lastly, the third section would analyse the method involved in assessing agriculture-product zakat as mentioned in the Sabil al-Muhtadin scripture, especially the part that determines the agriculture zakat rates. Therefore, it would be argued that although the debate adduced by Syeikh Muhammad Arsyad al-Banjari on the assessment of agriculture-product zakat as mentioned in the Sabil al-Muhtadin scripture had considered the situation at the time the
\end{abstract}


scripture was written; hence, due to the needs of present moment, there arises a need to improve the assessment of agriculture-product zakat, especially in Malaysia.

Keywords: zakat distribution, hardcore poor and impowerished, the present situation and locality

\section{Pendahuluan}

Zakat merupakan rukun Islam yang ketiga. Hal ini berdasarkan pesanan Rasulullah SAW ketika mengutuskan Muaz bin Jabal r.a. ke Yaman yang bermaksud: "Ajaklah mereka bersyahadah bahawa tidak ada Tuhan melainkan Allah dan bahawasanya Aku adalah utusan Allah. Jika mereka mentaatinya maka hendaklah engkau memberitahu mereka bahawa Allah memfardukan ke atas mereka solat lima waktu sehari semalam. Maka jika mereka mentaatinya, hendaklah engkau memberitahu mereka bahawa Allah memfardukan kepada mereka menunaikan zakat pada harta mereka. Harta itu diambil daripada orang kaya dan diberikan kepada orang miskin dalam kalangan mereka" (alBukhari, 1996).

Rukun zakat ini direalisasikan dengan mengambil harta daripada golongan kaya dan diberikan kepada golongan miskin. Dalam perkataan lain, mengagihkan semula kekayaan supaya tidak tertumpu dalam kalangan orang kaya sahaja. Dalam hal ini, Allah (s.w.t) berfirman yang bermaksud: "Apa saja harta rampasan (fay') yang diberikan Allah kepada Rasul-Nya (dari harta benda) yang berasal dari penduduk kota-kota maka adalah untuk Allah, untuk Rasul, kaum kerabat, anak-anak yatim, orang-orang miskin dan orang-orang yang dalam perjalanan, supaya harta itu jangan beredar dalam kalangan orang kaya sahaja antara kamu. Apa-apa yang diberikan Rasul kepadamu, maka terimalah. Dan apa-apa yang dilarangnya bagimu, maka tinggalkanlah. Dan bertakwalah kepada Allah. Sesungguhnya Allah amat keras hukumannya" (Surah al-Hasyr, 59:7). Ia direalisasikan secara serius oleh
Khulafa' al-Rasyidin. Khalifah Abu Bakar alSiddiq misalnya, semasa menghadapi golongan yang enggan menunaikan zakat telah membuat keputusan memerangi golongan tersebut.

Para ulama membahagikan harta-harta yang diwajibkan zakat kepada lima kategori. Ia meliputi pertama, al- 'ayn iaitu emas dan perak; kedua, al-tijarah iaitu perniagaan; ketiga, alharth iaitu pertanian; keempat al-masyiyyah, iaitu ternakan; dan kelima, al-rikaz iaitu hasil bumi (Al-Zuhaili, 1994). Namun, kaedah taksiran zakat digubal dari semasa ke semasa supaya selari dengan suasana dan keperluan pada masa itu. Hal ini berlaku pada zaman Khalifah al-Rasyidin, zaman para sahabat dan seterusnya pada zaman tabi'in.

Namun begitu, para ulama berbeza pendapat tentang kaedah taksiran zakat. Hal ini disebabkan oleh perbezaan tafsiran terhadap perkataan harta dalam al-Qur'an itu. Antaranya firman Allah SWT yang bermaksud: "Ambillah (sebahagian) daripada harta (amwal) mereka menjadi sedekah (zakat), (supaya dengannya) engkau membersihkan mereka (daripada dosa) dan menyucikan mereka (daripada akhlakyang buruk) dan doakanlah untuk mereka, kerana sesungguhnya doa mu itu menjadi ketenteraman bagi mereka dan (ingatlah) Allah Maha Mendengar, lagi Maha Mengetahui" (Surah al-Taubah, 9:103).

Al-Qur'an sendiri menyebut harta-harta yang diwajibkan zakat dalam dua bentuk. Pertama, dalam bentuk umum; dan kedua, dalam bentuk spesifik (Mahmood Zuhdi, 2003). Dalam bentuk umum, al-Qur'an hanya menyebut perkataan sebahagian harta (Surah al-Taubah, 9: 103) atau harta-harta (Surah al-Dhariyat, 51:19). Dalam bentuk spesifik pula, al-Qur'an menyebut hartaharta seperti emas dan perak (Surah al-Taubah, 9:34), hasil pertanian (Surah An'am, 6:141), perniagaan dan hasil galian (Surah al-Baqarah, 2: 267). Kedua-dua bentuk tersebut turut disebut dalam al-Sunnah Rasulullah SAW (Mahmood Zuhdi Abd. Majid, 2003). Dalam bentuk umum, Rasulullah SAW hanya menyebut perkataan 
harta-harta, manakala dalam bentuk spesifik, Rasulullah SAW menyebut jenis-jenis harta iaitu emas dan perak, barangan perniagaan, hasil pertanian seperti gandum, barli dan anggur, ternakan seperti kambing, lembu dan unta; dan hasil galian.

Sehubungan dengan itu, dari masa ke semasa para ulama membincangkan persoalan zakat ini dalam kitab masing-masing. Ia turut dibincangkan oleh Syeikh Muhammad Arsyad al-Banjari dalam kitab beliau Sabil al-Muhtadin. Persoalannya, apakah isu-isu tentang taksiran zakat pertanian yang telah dibincangkan oleh Syeikh Muhammad Arsyad al-Banjari dalam kitab tersebut? Bagaimanakah faktor semasa dan keadaan setempat diambikira oleh beliau semasa menyelesaikan isu-isu tersebut?

Dengan menggunakan kaedah analisis kandungan, artikel ini menganalisis taksiran zakat pertanian yang dibincangkan oleh Syeikh Muhammad Arsyad al-Banjari. Ia mengandungi tiga bahagian. Pertama, sorotan ringkas biodata Syeikh Muhammad Arsyad al-Banjari sebagai latar belakang; kedua, membincangkan taksiran zakat hasil pertanian dalam kitab Sabil alMuhtadin; dan ketiga, menganalisis kaedah taksiran zakat hasil pertanian dalam Sabil alMuhtadin khususnya dalam menentukan kadar zakat pertanian dan amalan masa kini dalam taksiran zakat pertanian.

\section{Biodata Syeikh Muhammad Arsyad Al-Banjari}

Syeikh Muhammad Arsyad al-Banjari adalah antara ulama yang paling terkenal dari Borneo. Nama penuh beliau ialah Syeikh Muhammad Arsyad bin Abdullah bin Abdur Rahman alBanjari. Beliau telah dilahirkan pada malam Khamis, pukul 3.00 pagi pada 15 Safar $1122 \mathrm{H}$ bersamaan 17 Mac 1710M di Kampung Lok Gabang, Martapura, Banjarmasin. Beliau meninggal dunia pada malam Selasa pada 6 Syawal $1227 \mathrm{H}$ bersamaan 13 Oktober $1812 \mathrm{M}$ ketika berusia 105 tahun (Wan Mohd Shaghir, 2005)
Syeikh Muhammad Arsyad al-Banjari mendapat pendidikan penuh di istana sehingga usianya mencapai 30 tahun. Beliau menyambung pengajian di Makkah dan Madinah. Beliau berguru dengan Syeikh Muhammad bin Sulaiman al-Kurdi, Syeikh Atha'ullah atau Ata'illah bin Ahmad al-Misriy, Syeikh Muhammad bin Abd Karim al-Qadiri, Syeikh Ahmad bin Abd Mun'im al-Damanhuri, Syeikh Hasan bin Ahmad Akisy al-Yamani, Sheikh Salim bin Abdullah al-Basri dan Syeikh Muhammad bin Abdul Karim al-Sammani alMadani. Beliau turut berguru dengan ulamaulama yang berasal dari dunia Melayu seperti Syeikh Abdur Rahman bin Abdul Mubin Pauh Bok al-Fathani, Syeikh Muhammad Zain bin Faqih Jalaluddin Aceh dan Syeikh Muhammad 'Aqib bin Hasanuddin al-Falimbani (Wan Mohd Shaghir, 2009). Setelah berada selama tiga puluh tahun di Makkah dan lima tahun di Madinah, Syeikh Muhammad Arsyad al-Banjari pulang ke tanah air untuk menyebarkan Islam.

Antara sahabat beliau yang telah diketahui ialah Syeikh 'Abdus Shamad al-Falimbani; Syeikh 'Abdur Rahman al-Mashri al-Batawi iaitu datuk kepada Sayyid 'Utsman Mufti Betawi yang terkenal; Syeikh 'Abdul Wahhab Sadenreng Daeng Bunga Wardiyah berasal dari Bugis, yang kemudian menjadi menantu kepada Syeikh Muhammad Arsyad bin 'Abdullah al Banjari; Syeikh Ahmad Razzah orang Mesir; Syeikh Muhammad Nafis bin Idris al-Banjari, pengarang kitab ad-Durr an-Nafis; Syeikh Mahmud bin Kinan al-Falimbani; Syeikh Muhammad 'Asyiquddin bin Shafiyuddin alFalimbani; Syeikh Muhammad Shalih bin 'Umar as-Samarani (Semarang) yang digelar dengan Imam Ghazali Shaghir (Imam Ghazali Kecil); Syeikh 'Utsman bin Hasan ad-Dimyati; Syeikh 'Abdur Rahman bin 'Abdullah bin Ahmad atTarmasi; Syeikh Haji Zainuddin bin 'Abdur Rahim bin 'Abdul Lathif bin Muhammad Hasyim bin 'Abdul Mannan bin Ahmad bin 'Abdur Rauf al-Fathani; Kiyai Musa Surabaya (Wan Mohd Shaghir, 2005)

Pengaruh tulisan beliau menular ke seluruh 
dunia Melayu kerana hampir semua ulama dunia Melayu mengenali tulisan beliau yang paling masyhur iaitu Sabil al-Muhtadin (Wan Mohd Shaghir, 2005). Ketika pulang ke Banjar, beliau sangat sibuk mengajar dan menyusun hal-hal yang berkaitan dengan dakwah, pendidikan dan pentadbiran Islam. Namun begitu, beliau masih sempat beberapa buah kitab lain. Antaranya ialah Tuhfah al-Raghibin fi Bayan Haqiqat Iman al-Mu'minin wa ma Yufsiduhu Riddah al-Murtaddin,(1188 H/1774M), Luqtah al'Ajlan fi al-Haid wa al-Istihadahwa al-Nifas al-Nisyan,(1192 H/1778), Sabil al-Muhtadin li al-Tafaqquh fi Amr al-Din, (1195H/1780M), Risalah Qaul al-Mukhtasar, (1196H/1781M), Kitab Bab 'an Nikah, Bidayah al-Mubtadi'wa 'Umdah al-Awlad, Kanz al-Ma'rifah, Kitab al-Faraid, Bulugh al-Maram, Fath al-Rahman, Arkan Ta'lim al-Sibyan, Hasyiyah Fath alWahhab dan Mushaf al-Qur'an al-Karim . (Wan Mohd Shaghir, 2005)

Kitab Sabil al-Muhtadin li al-Tafaqquh fi Amr al-Din atau lebih dikenali dengan nama Sabil alMuhtadin adalah tulisan beliau yang termasyhur. Kitab ini berada di beberapa perpustakaan besar di Makkah, Mesir, Turki, dan Beirut. Kitab ini amat popular di Nusantara yang merangkumi Indonesia, Malaysia, Singapura, Thailand, Kemboja dan Brunei. Perbahasan dalam kitab Sabil al-Muhtadin meliputi antara lain ialah persoalan solat, zakat, puasa dan haji.

\section{Taksiran Zakat Pertanian Dalam Sabil Al-Muhtadin}

Ketika membincangkan bab zakat dalam kitab Sabil al-Muhtadin, Syeikh Muhammad Arsyad al-Banjari memulakan dengan menerangkan harta yang dikeluarkan itu dinamakan zakat disebabkan menyucikan harta, memperbaikinya dan menambah kebaikan ataupun berkat (Muhammad Arsyad al-Banjari, 2008). Inilah sebenarnya tujuan zakat. Ia bukan sekadar sebagai satu jaminan keselamatan sosial bagi golongan miskin, tetapi untuk memastikan kedaan ekonomi yang seimbang melalui agihan semula kekayaan dalam kalangan masyarakat.
Tujuan zakat ini disebut dalam al-Qur'an yang bermaksud: "Ambillah (sebahagian) daripada harta mereka menjadi sedekah (zakat), supaya dengannya engkau membersihkan mereka dan menyucikan mereka; dan doakanlah untuk mereka, kerana sesungguhnya doamu itu menjadi ketenteraman bagi mereka" (Surah al-Taubah, 9:103).

Dalam kitab Sabil al-Muhtadin, harta wajib zakat dibahagikan kepada empat kategori. Pertama, zakat ternakan; kedua, zakat emas dan perak; ketiga, zakat ma 'adin (galian), rikaz, dan perniagaan; dan keempat, zakat pertanian. Untuk taksiran zakat ternakan pula adalah pertama, ternakan diwajibkan zakat terhad kepada unta, lembu, kerbau, kambing dan biri-biri; kedua, ternakan tersebut hendaklah cukup nisabnya; dan ketiga, kadar yang dikenakan berbeza-beza mengikut jenis ternakan. Muhammad Arsyad al-Banjari (2008) menyebutnya seperti berikut: "Syarat diwajibkan zakat binatang ternak itu ialah pertama binatang itu terdiri dari unta, lembu, kerbau, kambing dan biri-biri. Kerana itu tidak wajib mengeluarkan zakat binatang yang selain dari yang disebutkan di atas seperti kuda, badak, kijang, rusa dan sebagainya. Kedua hendaklah binatang itu cukup nisabnya" (hal. 508).

Zakat emas dan perak dikeluarkan pada kadar 2.5 peratus setelah cukup haul iaitu setelah disimpan selama satu tahun. Nisabnya ialah 20 misqal. Emas dan perak yang dijadikan perhiasan tidak diwajibkan zakat. Namun, sekiranya ia dijadikan perhiasan untuk orang lelaki, maka emas dan perak itu diwajibkan zakat. Sekiranya perhiasan itu diperoleh melalui pusaka dan telah cukup haul, maka diwajibkan zakat. Syeikh Muhammad Arsyad al-Banjari (2008) menyebutnya seperti berikut: "Tetapi kalau diketahuinya umpamanya didapatinya dan perwarisan dan keluarganya dan baru diketahuinya sesudah berlalu setahun, maka wajib zakatnya" (hal. 526).

Syeikh Muhammad Arsyad al-Banjari membincangkan zakat harta ma'adin, rikaz 
dan barangan perniagaan dalam satu bab. Ma'adin ialah semua galian yang diperoleh dari perut bumi sama ada di darat atau di laut seperti emas, perak dan bijih timah. Ma'adin dikenakan zakat pada kadar 2.5 peratus dengan memakai emas dan perak sebagai nisab. Zakat wajib dikeluarkan semasa hasil galian itu diperoleh setelah dibersihkan daripada tanah dan pasir tanpa menunggu cukup haul. Syeikh Muhammad Arsyad al-Banjari (2008) menyebut seperti berikut: “...melombong emas atau perak di tanah miliknya atau tanah yang belum pernah dimiliki orang dan diperolehnya senisab, maka wajib mengeluarkan zakatnya sebanyak 2.5 peratus ketika itu juga. ... Waktu wajib mengeluarkan zakat emas dan perak hasil perlombongan ini pada saat dibersihkan dari tanah dan pasir" (hal. 527-528).

Rikaz ialah harta yang tersimpan di dalam bumi dan terdapat tanda-tanda yang menunjukkan ia tersimpan sebelum kedatangan Islam. Rikaz dikenakan zakat pada kadar 5.0 peratus dengan memakai emas dan perak sebagai nisab. Zakat dikeluarkan semasa harta itu diperoleh atau ditemui tanpa menunggu cukup haul. Syeikh Muhammad Arsyad al-Banjari (2008) menyebut seperti berikut: "Tidak disyaratkan pada zakat rikaz ini haul tetapi zakatnya dikeluarkan setelah ditemukan. ...Dan wajib dikeluarkan 5.0 peratus ketika itu juga baik didapati dengan digali atau kerana dilanda air bah atau tanah runtuh" (hal. 528-529).

Zakat perniagaan dikenakan ke atas barangan perniagaan sahaja. Syeikh Muhammad Arsyad al-Banjari membincangkan secara terperinci syarat-syarat wajib zakat barangan perniagaan. Perbahasan itu meliputi dua kategori. Pertama ialah syarat-syarat sesuatu barangan yang boleh digolongkan sebagai barangan perniagaan. Misalnya beliau menyebut seperti berikut: "Hendaklah barang itu diniatkan untuk diperniagakan. ..diniat dipermulaan akad untuk memiliki barang itu. ...melalui perjanjian yang bersifat imbal balik seperti jual-beli" (hal, 530).

Kategori kedua ialah syarat-syarat nisab ke atas sesuatu barangan perniagan. Untuk nisab ini, beliau antara lain menyebut seperti berikut: "Jangan diqasadkan barangan perniagaan itu pada pertengahan tahun dan kalau diqasadkan menyimpan barangan perniagaan itu pada pertengahan tahun, maka terputuslah haul peniagaan" (hal. 531).

Taksiran zakat perniagaan dibuat berasaskan nilai barangan perniagaan itu sendiri. Syeikh Muhammad Arsyad al-Banjari (2008) menjelaskannya seperti berikut: "Zakat barangan perniagaan sebanyak 2.5 peratus dari harga barang. Yang diwajib dikeluarkan 2.5 peratus seperti emas dan perak kerana dikira nilainya. Zakat perniagaan dikira dari nilainya bukan dari bendanya. Kerana itu tidak boleh mengeluarkan zakat barangan perniagaan ini dari benda yang diperniagakan” (hal. 531).

Syeikh Muhammad Arsyad al-Banjari (2008) membincangkan tiga perkara utama dalam taksiran zakat pertanian. Pertama, tentang jenis pertanian yang diwajibkan zakat. Menurut beliau, hasil pertanian wajibkan zakat adalah pertama, hasil pertanian yang boleh mengenyangkan; dan kedua ia boleh menguatkan tubuh badan. Ia meliputi bijirin dan kekacang. Beliau menyebut seperti berikut: "Yang mengenyangkan itu ada kalanya pada tumbuh-tumbuhan seperti kurma dan danggur, dan kadang-kadang dari bijibijian seperti gandum dan jelai iaitu sejenis gandum namun bijinya lebih panjang dan lebih besar dari gandum. ... dan semua jenis kacangkacangan baik berwarna putih, hijau, merah atau hitam" (hal. 518).

Kedua, kadar zakat hasil pertanian pula bergantung kepada kaedah pengairan yang digunakan. Jika air itu diperoleh secara percuma, maka kadarnya ialah 10 peratus. Sebaliknya, jika air yang digunakan itu melibatkan kos iaitu berbayar, maka kadarnya ialah 5 peratus. Jika kaedah pengairan yang digunakan adalah kombinasi kedua-dua kaedah pengairan iaitu percuma dan berbayar, maka kadarnya ialah 7.5 peratus. Syeikh Muhammad Arsyad alBanjari (2008) menyebut seperti berikut: “... 
menyiraminya melalui air hujan, air sungai, air perigi, atau mata air, dengan tidak mengupah, maka zakatnya sebanyak 10 peratus. Zakat hasil yang disirami dengan air perigi, air hujan baik dengan dipikul oleh manusia atau diangkut oleh binatang, atau dengan kincir air, maka zakatnya sebanyak 5 peratus. ...melalui kedua cara tadi..., maka kadar zakatnya sebanyak 7.5 peratus" (hal. 519-520).

Jika tidak dapat dipastikan kaedah pengairan yang mana satu banyak digunakan atau kaedah pengairan mana yang kurang digunakan, maka kaedah pengairan yang paling banyak digunakan semasa penuaian. Oleh itu, kadar zakat yang dikenakan adalah mengikut kaedah pengairan yang digunakan pada masa itu. Syeikh Muhammad Arsyad al-Banjari (2008) menyebut seperti berikut: "Dan kalau disirami dengan kedua cara yang diterangkan di atas, tetapi tidak sama dan diketahui dengan cara yang mana terbanyak dan dengan cara yang mana yang sedikit, maka zakatnya adalah disesuaikan dengan cara yang terbanyak waktunya sampai masa penuaiannya" (hal. 519-520).

Ketiga, nisab hasil tanaman bijirin makanan asasinya adalah 300 gantang beras atau 600 gantang padi. Menurut Muhammad Arsyad al-Banjari (2008), ini adalah disebabkan 600 gantang padi apabila dijadikan beras biasanya menjadi 300 gantang. Dengan kata lain, penentu nisab padi adalah 300 gantang beras. Beliau menyebut seperti berikut: "Sedang kulitnya tidak termasuk ke dalam hitungan nisab. Terkadang padi yang 600 gantang apabila dijadikan beras kurang dari 300 gantang, maka tidaklah wajib mengeluarkan zakatnya. Terkadang beras yang 300 gantang dari padi yang kurang dari 600 gantang, maka wajiblah mengeluarkan zakatnya" (hal. 519).

Nisab ini adalah ditetap pada lima awsuq. Satu awsuq ialah enam puluh gantang. Oleh sebab itulah, nisab ditetapkan pada 300 gantang. Sesuatu jenis bijirin tidak boleh dicampur dengan bijirin lain dalam menentukan nisab. Padi misalnya tidak boleh dicampur dengan gandum. Syeikh Muhammad Arsyad al-Banjari (2008) menyebut seperti berikut: "Padi jangan ditambah dengan dengan jenis yang lain untuk mencukupkan nisabnya, umpamanya gandum yang dicampur dengan jelai (jenis gandum yang lebih besar ukurannya), kurma tidak dicampur dengan anggur kerana jenisnya berlainan. Tetapi wajib mencampur yang sejenis untuk mencukupkan nisab, umpamanya kurma mukalla dengan kurma bumi..." (hal. 519).

Jika seseorang memiliki banyak sawah, tetapi tidak cukup nisab, maka hendaklah digabungkan semua hasil pertanian yang diperoleh, walaupun menggunakan bentuk pengairan yang tidak sama. Namun kadar zakat yang digunakan adalah tertakluk kepada bentuk pengairan yang digunakan. Syeikh Muhammad Arsyad al-Banjari (2008) menyebut seperti berikut: "Kalau seseorang memiliki dua bidang sawah, yang satu disirami melalui hujan dan yang satu lagi disirami dengan usaha dan masing-masing hasil dan kedua sawah itu tidak sampai jumlah nisabnya, maka keduanya digabungkan untuk mencukupkan nisab sekalipun berbeza jumlah yang dikeluarkan. Kerana sawah yang pertama wajib dikeluarkan sebanyak 10 peratus dan sawah kedua sebanyak 5 peratus" (hal. 521).

Setelah dikeluarkan zakat, hasil pertanian yang tersimpan tidak lagi dikenakan zakat, walaupun tersimpan bertahun-tahun. Zakat hasil pertanian dikenakan sekali sahaja semasa ia dituai. Syeikh Muhammad Arsyad al-Banjari (2008) menyebut seperti berikut: "Apabila telah dikeluarkan zakat buah-buahan dan biji-bijian, yang tersimpan sampai tahun berikutnya dan jumlah cukup nisab atau lebih, maka tidak wajib mengeluarkan zakatnya kerana zakat tumbuh-tumbuhan hanya sekali, berbeza dengan zakat binatang, emas dan perak wajib dikeluarkan pada setiap tahun selama masih sampai nisabnya" (hal. 523).

Dari segi kaedah taksiran zakat, perbahasan Syeikh Muhammad Arsyad al-Banjari (2008) dalam kitab Sabil al-Muhtadin boleh dibahagikan kepada tiga kategori. Pertama, 
zakat dikenakan ke atas harta dan hasil yang diperoleh dari harta tersebut. Kaedah ini hanya untuk zakat binatang ternakan. Nisab dan kadar zakat binatang ternakan berbeza-beza mengikut jenis binatang ternakan. Unta misalnya 5 ekor dengan kadar zakatnya seekor kambing; lembu 30 ekor dengan kadar zakatnya seekor lembu jantan berumur setahun; dan kambing 40 ekor dengan kadar zakatnya. Seekor kambing. Kadar zakatnya berubah mengikut bilangan binatang ternakan seperti yang ditetapkan oleh Rasulullah SAW.

Kedua, zakat dikenakan ke atas hasil yang diperoleh daripada harta tersebut sahaja. Nisab dan kadar zakat ke atas hasil ini berbeza-beza mengikut jenis hasilnya. Nisab hasil pertanian adalah sebanyak 300 gantang beras. Kadar zakat hasil pertanian adalah 5 peratus, 7.5 peratus atau 10 peratus. Nisab hasil ma 'adin dan rikaz adalah sebanyak 20 mithqal iaitu 85 gram. Kadar zakat hasil daripada perut bumi adalah 2.5 peratus untuk ma'adin, dan 5 peratus untuk rikaz.

Ketiga, zakat hanya dikenakan ke atas harta itu sahaja. Kaedah ini meliputi zakat emas, perak dan barangan perniagaan. Nisab emas dan barangan perniagaan adalah 20 mithqal iaitu 85 gram. Kadar zakat yang dikenakan adalah 2.5 peratus.

Kaedah taksiran zakat ini sebenarnya adalah berdasarkan maksud Hadith Rasulullah SAW sendiri. Taksiran harta-harta wajib zakat, amaun nisabnya, dan berapa kadar zakatnya terdapat dalam Hadith Rasulullah SAW sendiri (Yusuf al-Qaradawi, 1999:71).

\section{Taksiran Zakat Pertanian Dalam Sabil Al- Muhtadin Dan Amalan Masa Kini}

Dalam kitab Sabil al-Muhtadin, Syeikh Muhammad Arsyad al-Banjari (2008) mempamerkan beberapa perubahan dalam taksiran zakat hasil pertanian. Antara yang terserlah adalah kadar zakat hasil pertanian pada 7.5 peratus. Berdasarkan Hadith Rasulullah SAW, tiada kadar zakat hasil pertanian pada
7.5 peratus. Namun, hal ini sebenarnya selari dengan perkembangan hukum zakat itu sendiri. Dengan itu, perbincangan seterusnya akan merangkumi lima perkara. Pertama, tentang perkembangan hukum zakat melalui ijtihad; kedua, tentang hasil pertanian yang diwajibkan zakat; ketiga, tentang kadar dan nisab zakat pertanian; keempat, tentang zakat dikenakan sama ada terhadap hasil kasar atau hasil bersih; dan kelima, tentang pandangan fuqaha' terhadap kos sara hidup.

\section{Hukum Zakat dan Ijtihad}

Muhammad Saeed Siddiqi (1981) membuktikan bahawa hukum zakat telah berkembang berdasarkan ijtihad. Ia berlaku baik pada zaman Rasulullah SAW, zaman sahabat mahupun pada zaman tabi'in. Perkembangan dan perubahan hukum boleh dipengaruhi oleh beberapa faktor. Antara lain adalah perubahan sosio-politik, sosio-ekonomi, sosio-budaya dan perubahan nilai-nilai sosial. Hal yang sama berlaku kepada perkembangan hukum zakat. Perkembangan hukum zakat tersebut meliputi harta-harta zakat yang diwajibkan zakat dan kadar zakatnya. Hal ini mempamerkan bahawa kaedah perakaunan zakat adalah tidak rigid. Malah Mohd. Tamyes (2002) menegaskan proses ijtihad dalam perkembangan hukum zakat sepatutnya berlaku secara berterusan. Beliau menegaskan bahawa para ilmuwan Islam perlulah terbuka dalam menerima sebarang pembaharuan dan perubahan hukum yang telah ditinggalkan oleh kalangan fuqaha' silam.

Mujaini (1999) mendapati proses ijtihad dalam zakat sangat terserlah pada zaman Khulafa' alRasyidin. Antaranya ijtihad Khalifah Abu Bakar as-Siddiq dalam memerangi golongan yang enggan membayar zakat. Begitu juga dengan Khalifah Umar al-Khattab Khalifah Uthman b. Affan dan Khalifah Ali b. Abi Talib yang membuat keputusan tentang zakat berdasarkan ijtihad. Proses ijtihad ini diteruskan pada zaman tabi'in.

Semasa pemerintahan Khalifah Umar al- 
Khattab, paling tidak terdapat empat ijtihad yang telah dilaksanakan tentang zakat. Pertama, mengenakan zakat terhadap kuda walaupun pada zaman Rasulullah SAW kuda tidak dikenakan zakat. Kedua, asas zakat pertanian diperluaskan dengan mengenakan zakat terhadap kacang, kapas dan buah zaitun. Ketiga, hasil keluaran laut seperti ikan dan minyak turut dikenakan zakat. Madu dikenakan zakat pada kadar 5 - 10 peratus berdasarkan kepada guna tenaga yang digunakan bagi memproses hasil pengeluaran tersebut. Keempat, penalti turut dikenakan sekiranya pembayar zakat sengaja menipu taksiran zakat dengan dihukum denda sebanyak 20 peratus daripada barangan yang dizakatkan (Mujaini Tarimin, 1999).

Masalah zakat yang timbul ketika pemerintahan Khalifah 'Uthman b. Affan ialah tentang kewajipan zakat hutang. Siapa yang berkewajipan untuk menunaikan, sama ada pemberi hutang atau penerima hutang? Adakah zakat wajib ditunaikan setiap tahun ataupun setelah dibayar sepenuhnya? Khalifah 'Uthman memutuskan bahawa sesiapa yang mempunyai harta mengira semua harta kekayaan yang mereka punyai, kemudian menolak jumlah hutang yang ditanggung oleh mereka. Zakat dikeluarkan terhadap baki harta kekayaan yang dimiliki (Mujaini, 1999).

Paling tidak tiga ijtihad yang telah dibuat ketika pemerintah Khalifah Ali b. 'Abi Talib. Pertama, mengecualikan zakat terhadap unta disebabkan unta digunakan untuk pengangkutan dan tunggangan. Kedua, zakat terhadap kuda telah ditarik balik disebabkan kuda pada masa pemerintahan beliau digunakan untuk kerja pembajakan dan pengangkutan. Ketiga, kadar zakat unta boleh diganti seekor kambing biribiri. Setiap lima ekor unta dengan unta yang lebih muda atau tua dengan syarat dibayar ganti rugi kepada tuannya dua ekor kambing biri-biri atau 10 dirham (Mujaini, 1999).

Pada masa tabi'in, paling tidak terdapat enam bentuk perkembangan hukum zakat. Pertama, teori pembahagian harta zahir dan harta batin (al-mal al-zahira dan al-mal al-batina). Ia bertujuan menentukan pembayaran zakat dibuat kepada pihak pemerintah atau terus kepada asnaf zakat. Kedua, teori harta berkembang (al-mal al-nama'). Berkembang ditafsirkan mampu atau berpotensi untuk mendatangkan keuntungan. Zakat hanya dikenakan terhadap harta yang berkembang. Ketiga, zakat terhadap ma'adin dan al-rikaz. Ma'adin ialah segala galian yang diperoleh daripada perut bumi sama ada beku atau cair. Al-rikaz ialah harta benda yang tersimpan dalam bumi dan terdapat tanda-tanda yang menunjukkan ia tersimpan sebelum kedatangan Islam. Keempat, zakat hasil laut. Hasil laut meliputi semua yang dihasilkan daripada laut seperti mutiara, kasturi (anbar), ikan dan sebagainya. Kelima, zakat hasil madu. Keenam, zakat al-mal al-dimar. Al-amwal al-dimar ialah harta yang tiada dalam penguasaan pemilik. Zakat dikecualikan bagi tempoh waktu tersebut. Semasa tabi'in pula, perkembangan hukum zakat adalah berasaskan ijtihad, maslahat 'ammah (kepentingan awam) dan prinsip-prinsip keadilan (Siddiqi, 1981).

Ijtihad dalam hukum zakat ini berlaku disebabkan beberapa sebab. Antaranya, harta yang diwajibkan zakat berdasarkan al-Qur'an dan Sunnah dalam dua bentuk. Pertama, dalam bentuk umum; dan kedua, dalam bentuk spesifik (Mahmood Zuhdi, 2003). Dalam bentuk umum, al-Qur'an hanya menyebut perkataan sebahagian harta seperti "Ambillah zakat dari sebahagian harta mereka dengannya kamu membersihkan dan menyucikan mereka" (Surah al-Taubah, 9:103) atau harta-harta seperti "Dan pada harta-harta mereka ada hak untuk orang miskin yang meminta dan orang miskin yang tidak mendapat bahagian" (Surah al-Dhariyat, 51:19). Dalam bentuk spesifik pula, al-Qur'an menyebut emas dan perak seperti "Dan orangorang yang menyimpan emas dan perak dan tidak menafkahkannya pada jalan Allah maka beritahulah kepada mereka (bahawa mereka akan mendapat) seksa yang pedih" (Surah al-Taubah, 9:34), hasil pertanian seperti "Makanlah dari buahnya (yang bermacammacam itu) bila dia berbuah dan tunaikanlah 
haknya pada hari memetik hasilnya" (Surah al-An'am 6:141), hasil perniagaan dan hasil galian seperti "Hai orang-orang yang beriman, nafkahkanlah (di jalan Allah) sebahagian dari hasil usaha mu yang baik-baik dan sebahagian dari apa yang Kami keluarkan dari bumi untuk kamu" (Surah al-Baqarah 2:267). Meskipun al-Qur'an menyebut jenis-jenis harta tertentu dikenakan zakat (Surah al-Taubah 9:34; Surah al-An'am 6:141; dan Surah al-Baqarah, 2:267), tetapi tidak ada apa-apa kenyataan atau isyarat yang ia secara bersama menghadkan pengertian umum yang terdapat dalam ayatayat 19 daripada Surah al-Dhariyat dan ayat 103 daripada Surah al-Taubah. Ketiga-tiga ayat tersebut hanya menerangkan beberapa jenis harta yang diwajibkan zakat, tetapi ia tidak bermakna harta-harta lain tidak diwajibkan zakat (Mahmood Zuhdi, 2003).

Dalam bentuk umum, Rasulullah SAW hanya menyebut perkataan harta-harta, manakala dalam bentuk spesifik, Rasulullah SAW menyebut jenis-jenis harta, iaitu emas dan perak, barangan perniagaan, hasil pertanian seperti gandum, barli dan anggur, ternakan seperti kambing, lembu dan unta, dan hasil galian (Mahmood Zuhdi, 2003). Dalam perkataan lain, dalam menentukan harta yang diwajibkan zakat, al-Qur'an dan Sunnah menggunakan dua kaedah pendekatan. Pertama, pendekatan ijmal (global); dan kedua, pendekatan tafsil (terperinci).

Perubahan dalam taksiran zakat yang dibuat oleh Khulafa' al-Rasyidin boleh dibahagikan kepada empat kategori. Pertama, pemerintah telah menilai semula pelaksanaan hukum zakat yang telah ditetapkan sebelumnya dan mengubahnya bersesuaian dengan keadaan dan suasana semasa. Khalifah Umar al-Khattab misalnya mengenakan zakat ke atas kuda walaupun pada zaman Rasulullah SAW kuda dikecualikan daripada zakat. Sebaliknya semasa pemerintahan Khalifah Ali b. Abi Talib, kuda tidak dikenakan zakat.

Kedua, pemerintah boleh memperluaskan asas zakat dengan mengenakan zakat ke atas sesuatu harta yang baru ditemui atau baru wujud dalam kalangan masyarakat. Khalifah Umar al-Khatab misalnya memperluaskan asas zakat ternakan dengan mengenakan zakat ke atas kuda, asas zakat pertanian dengan mengenakan zakat ke atas kacang, kapas dan buah zaitun serta beberapa jenis hasil keluaran laut.

Ketiga, pemerintah boleh membuat perubahan ke atas kadar zakat yang diamalkan. Khalifah Umar al-Khatab misalnya mengenakan zakat ke atas madu pada kadar 5 - 10 peratus tertakluk kepada guna tenaga yang digunakan dalam memproses hasil tersebut. Khalifah Uthman b. Affan pula mengenakan zakat ke atas harta bersih setelah ditolak semua hutang. Khalifah Ali b. Abi Talib memperkenalkan kadar zakat, iaitu setiap lima ekor unta boleh diganti dengan unta yang lebih muda atau tua dengan syarat dibayar ganti rugi kepada tuannya dua ekor kambing biri-biri atau 10 dirham.

\section{Hasil Pertanian Wajib Zakat}

Syeikh Muhammad Arsyad al-Banjari (2008) menyebut antara syarat hasil pertanian yang diwajibkan zakat ialah hasil pertanian yang boleh mengenyangkan. Dalam perkataan lain, zakat diwajibkan terhadap hasil pertanian yang menjadi makanan asasi penduduk sesebuah negeri. Di Malaysia, makanan asasi yang disepakati ialah beras yang dihasilkan daripada padi, maka padi diwajibkan zakat (JAWHAR, 2008).

Walau bagaimanapun, hasil pertanian yang diwajibkan zakat mendapat tafsiran yang pelbagai dalam kalangan ulama. Hal ini kerana al-Qur'an menyebut hasil pertanian diwajibkan zakat dalam bentuk umum. Antaranya seperti firman Allah SWT yang bermaksud: "Wahai orang-orang yang beriman! belanjakanlah (pada jalan Allah) sebahagian daripada hasil usaha kamu yang baik-baik dan sebahagian daripada apa yang Kami keluarkan daripada bumi untuk kamu...." (Surah al-Baqarah, $2: 267)$. 
Umumnya, terdapat empat kategori pendapat tentang hasil pertanian yang diwajibkan zakat (al-Qaradawi, 1999). Pertama, zakat diwajibkan hanya ke atas gandum, barli, kurma dan anggur; kedua, zakat diwajibkan ke atas hasil pertanian yang dijadikan makanan asasi dan boleh disimpan lama; ketiga, zakat diwajibkan ke atas hasil pertanian yang boleh dikeringkan, disimpan lama dan disukat; keempat, zakat diwajibkan ke atas semua hasil pertanian.

Pertama, zakat diwajibkan hanya terhadap empat hasil pertanian sahaja. Ia meliputi gandum, barli, kurma dan anggur. Ini pendapat Ibn Umar dan beberapa ulama salaf. Musa Ibn Talhah, Hasan al-Basri, Ibn Sirin, al-Syabi, al-Hasan Ibn Salih, Ibn Abi Laila, Ibn al-Mubarak dan Abu Ubayd turut berpendapat sedemikian (al-Qaradawi, 1999). Hal ini adalah berdasarkan perintah Rasulullah kepada Abu Musa al-Asy'ari dan Mu'az Ibn Jabal supaya tidak mengambil zakat kecuali daripada empat hasil pertanian tersebut. Hal ini disokong oleh Hadis Musa bin Talhah yang turut menyebut empat jenis hasil pertanian ini yang diwajibkan zakat (Ibn Hajar, 1992).

Kedua, zakat diwajibkan terhadap hasil pertanian yang dijadikan makanan asasi dan boleh disimpan lama. Ini pendapat Imam Malik dan Imam al-Syafi'i. Makanan asasi adalah makanan yang mengenyangkan secara 'uruf kepada sesuatu bangsa seperti padi, gandum, barli dan jagung. Menurut Imam Malik dan Imam al-Syafi'i, zakat tidak dikenakan terhadap buah-buahan kecuali kurma dan anggur, dan bijirin lain kecuali yang menjadi makanan utama. Bagaimanapun, terdapat perbezaan pendapat dalam kalangan ulama al-Syafi'i terhadap zakat buah zaitun. Perbezaan pendapat dalam kalangan Maliki turut berlaku terhadap zakat buah tin (al-Qaradawi, 1999)

Ketiga, zakat diwajibkan terhadap hasil pertanian yang boleh dikeringkan, disimpan lama dan disukat. Ini pendapat Imam Ahmad Ibn Hanbal. Dengan itu, apa-apa sahaja hasil pertanian yang memenuhi kriteria tersebut diwajibkan zakat sama ada bijirin atau buah-buahan. Ia tidak tertakluk sama ada hasil pertanian tersebut menjadi makanan asasi ataupun sebaliknya. Namun, buah-buahan yang boleh dimakan, tetapi bukan tujuan mengenyangkan adalah dikecualikan zakat. Sayur-sayuran turut dikecualikan zakat kerana tidak memenuhi kriteria di atas (al-Qaradawi, 1999)

Keempat, zakat diwajibkan terhadap semua hasil pertanian. Zakat dikenakan ke atas semua jenis hasil pertanian sama ada diusahakan ataupun tumbuh sendiri, asalkan boleh diambil manfaat. Ini pendapat Imam Abu Hanifah. Ia berdasarkan dalil daripada pengertian umum al-Qur'an, iaitu apa-apa yang dikeluarkan dari bumi (Surah al-Baqarah, 2:267), dan tunaikan hak pada hari menuai (al-An'am, 6: 141). Mengikut Ibn Hazm, pandangan yang sama dipegang oleh 'Umar Abdul Aziz, Ibrahim alNakha'i, Hammad Abi Sulaiman dan Mujahid (al-Qaradawi, 1999).

Al-Qaradawi (1999) merumuskan pandangan Abu Hanifah yang paling sesuai diutamakan. Ia merupakan pandangan 'Umar Abdul Aziz, Mujahid, Hammad, Daud dan al-Nakha'i iaitu zakat dikeluarkan dari segala perkara yang dikeluarkan dari bumi. Inilah pandangan yang didokong oleh pengertian umum al-Qur'an dan al-Sunnah. Ia selaras dengan hikmat perundangan zakat. Selanjutnya al-Qaradawi (1999) membuat kesimpulan berikut: "Adalah kurang bijaksana, pada pandangan kita, kalau Syariat Islam mewajibkan zakat atas para petani yang menanam gandum dan barli tetapi mengecualikannya daripada para pengusaha ladang limau, mangga dan epal" (hal. 229).

\section{Kadar dan Nisab Zakat Pertanian}

Dalam kitab Sabil al-Muhtadin, jelas Syeikh Muhammad Arsyad al-Banjari mempamerkan keadaan semasa dan keperluan setempat mempengaruhi kaedah taksiran zakat hasil pertanian. Misalnya jika kaedah pengairan yang digunakan adalah kombinasi kedua-dua kaedah pengairan iaitu percuma dan berbayar, 
maka kadar zakatnya adalah 7.5 peratus. Kadar ini tidak ditemui dalam Hadis Rasulullah SAW. Syeikh Muhammad Arsyad al-Banjari (2008) menyebut seperti berikut: "Kalau tanah perkebunan atau pertanian itu disirami melalui kedua cara tadi seperti sebahagiannya dengan air hujan sebahagiannya lagi dengan usaha atau tidak diketahui bagaimana cara menyiraminya, maka jumlah (kadar) zakatnya sebanyak 7.5 peratus" (hal. 520).

Lebih daripada itu, sekiranya tidak dapat dipastikan kaedah pengairan yang paling banyak digunakan, maka kadar zakat dikenakan mengikut kaedah pengairan yang digunakan pada masa menuai. Syeikh Muhammad Arsyad al-Banjari (2008) menyebut seperti berikut: "Dan kalau disirami dengan kedua cara yang diterangkan di atas, tetapi tidak sama dan diketahui dengan cara yang mana terbanyak dan dengan cara yang mana yang sedikit maka zakatnya adalah disesuaikan dengan cara yang terbanyak waktunya sampai masa penuaiannya" (hal. 520).

Muhammad Arsyad al-Banjari (2008) seterusnya menjelaskan, sekiranya berlaku pertikaian antara pemilik sawah dengan petugas zakat, maka kaedah pengairan yang didakwa oleh pemilik sawah yang diterima. Beliau menyebut seperti berikut: "Kalau berbeza pendapat antara pemilik sawah dengan pemungut zakat, menurut pemilik disirami dengan usaha dan menurut pemungut dengan hujan, maka dalam hal ini yang dibenarkan adalah pemilik sawah" (hal. 520).

Pendapat Muhammad Arsyad al-Banjari (2008) ini terpakai sehingga sekarang. Di Malaysia misalnya kadar zakat hasil pertanian adalah tertakluk kepada kaedah pengairan yang digunakan. Bagi tanaman yang disiram dengan dengan air tanpa menggunakan tenaga seperti air hujan, maka kadar zakatnya ialah 10 peratus. Bagi tanaman yang disiram dengan air yang diangkut atau dibeli, maka kadar zakatnya ialah 5 peratus. Bagi tanaman yang disiram dengan menggunakan 50 peratus disiram dengan air hujan dan 50 peratus dengan air yang diangkut, maka kadar zakatnya ialah 7.5 peratus (JAWHAR, 2008). Namun, jika ada kaedah pengairan yang tidak jelas dan pertikaian antara pemilik sawah dengan pihak institusi zakat, ia tidak dinyatakan secara terang.

Ketiga-tiga kadar zakat tersebut misalnya dipakai oleh negeri Pahang dan Sarawak. Hal ini kerana mungkin terdapat petani yang menggunakan kedua-dua kaedah pengairan. Negeri Johor, Kedah dan Kelantan menggunakan kadar 10 peratus. Kadar ini dipakai kerana pertanian di negeri-negeri tersebut menggunakan air hujan dan air sungai yang tidak memerlukan kos yang tinggi. Negeri Terengganu, Melaka dan Perak pula menggunakan kadar 5 peratus dan 10 peratus. Kadar 5 peratus apabila kos yang tinggi digunakan, sebaliknya jika kos yang rendah seperti penggunaan air hujan, maka kadarnya 10 peratus (Asmak et. al., 2010).

Menurut Muhammad Arsyad al-Banjari (2008), penentu nisab padi adalah 300 gantang beras. Menurut beliau, 600 gantang padi biasa bersamaan 300 gantang. Namun ini bukanlah suatu persamaan mutlak. Hal ini kerana 600 gantang padi tidak semestinya sama dengan 300 gantang beras. Beliau menyebut seperti berikut: "Sedang kulitnya tidak termasuk ke dalam hitungan nisab. Terkadang padi yang 600 gantang apabila dijadikan beras kurang dari 300 gantang, maka tidaklah wajib mengeluarkan zakatnya. Terkadang beras yang 300 gantang dari padi yang kurang dari 600 gantang, maka wajiblah mengeluarkan zakatnya" (hal. 519).

Di Malaysia, kadar nisab hasil padi digunakan ukuran padi itu sendiri, bukannya beras. Kadar nisab mengikut ukuran gantang berbeza mengikut negeri. Namun, semua negeri menggunakan 5 awsuq padi sebagai ukuran nisab bukannya beras. Ukuran 5 awsuq padi ini mempamerkan ukuran gantang yang berlainan. Ukuran paling rendah dipakai oleh Negeri Kelantan iaitu 358 gantang. Ukuran paling tinggi dipakai oleh Melaka dan Pahang iaitu 
400 gantang. Kebanyakan negeri menggunakan ukuran 363 gantang. Ia dipakai oleh negeri Johor, Kedah, Selangor, Negeri sembilan, Perak dan Pulau Pinang. Negeri Perlis menggunakan ukuran yang berbeza iaitu 2 kunca 7 naleh (Asmak et. al., 2010).

Persoalannya, apakah ukuran yang dipakai oleh negeri di Malaysia itu tidak kurang daripada 300 gantang beras. Hal ini kerana menurut Muhammad Arsyad al-Banjari (2008), kadar nisab adalah 300 gantang beras. Apatah lagi, apakah semua ukuran gantang padi itu apabila ditukarkan kepada beras bersamaan 300 gantang beras?

\section{Zakat Terhadap Hasil Kasar Atau Hasil Bersih}

Dalam kitab Sabil al-Muhtadin, Syeikh Muhammad Arsyad al-Banjari (2008) tidak menjelaskan sama ada kos pengeluaran pertanian dibenarkan ditolak daripada hasil pertanian tersebut. Hal ini berlaku mungkin disebabkan kos pengeluaran pertanian semasa beliau mengarang kitab Sabil al-Muhtadin adalah tidak membebankan para petani. Dengan kata lain, beliau lebih menekankan kos pengairan yang terpaksa ditanggung oleh petani. Ini terpamer apabila beliau menyebut begitu terperinci tentang kadar zakat pertanian. Antara lain beliau meyebut "Dan kalau disirami dengan kedua cara yang diterangkan di atas (air hujan dan air diusahakan), tetapi tidak sama dan diketahui dengan cara yang mana terbanyak dan dengan cara yang mana yang sedikit maka zakatnya adalah disesuaikan dengan cara yang terbanyak ..." (hal. 520).

Ulama kontemporari seperti Al-Qaradawi (1999) berpendapat bahawa kos pengeluaran perlu ditolak terlebih dahulu sebelum zakat ditaksirkan. Hal ini kerana selain kos pengeluaran terdapat juga kos-kos lain seperti kos sara hidup yang terpaksa ditanggung oleh petani. Menurut beliau, bebanan dan kos merupakan faktor yang mempengaruhi penentuan hukum. Misalnya kaedah pengairan yang digunakan mempengaruhi penentuan kadar zakat pertanian. Kadar zakat berbeza disebabkan adanya bebanan dan kos, misalnya bagi kaedah pengairan yang menggunakan peralatan atau tenaga manusia kadar zakatnya ialah 5 peratus sahaja.

Dalam hal ini, Abu 'Ubayd (1991) meriwayatkan dua pendapat berlainan. Ibn 'Umar mengatakan semua kos sama ada untuk kos pengeluaran pertanian ataupun untuk kos sara hidup keluarga dibenarkan. Ibn 'Abbas r.a. pula mengatakan hanya kos pengeluaran pertanian sahaja dibenarkan. Hal ini berdasarkan satu riwayat daripada Jabir Ibn Zaid yang bermaksud: "Daripada Jabir Ibn Zaid, katanya: Dalam masalah seseorang yang berhutang dan kemudian membelanjakannya kepada keluarganya, kata Ibn 'Abas, dia perlu membayar apa yang dia belanjakan untuk kebunnya sahaja. Kata Ibn 'Umar pula, dia perlu membayar apa yang dia belanjakan atas kebunnya dan juga kepada keluarganya" (Abu Ubayd, 1991).

Di Malaysia, zakat pertanian perlu ditaksir secara profesional untuk mengetahui lebih awal jumlah yang wajib dibayar oleh pembayar zakat serta hak yang boleh diterima oleh pemerintah (amil) (JAWHAR, 2008). Pihak JAWHAR turut memberi contoh taksiran zakat padi. Antara kos yang dibenarkan ditolak adalah pertama, kos baja dan racun; kedua, kos sewa jika berkaitan; ketiga, kos upah tenaga kerja dan penuaian; keempat, kos pengangkutan yang terlibat. Maka hanya baki bersih setelah ditolak semua kos tersebut dikenakan zakat.

Jabatan Mufti Kerajaan Negeri Kelantan (1999) turut memfatwakan padi yang dihasilkan daripada projek penanaman padi secara estet diwajibkan zakat ke atas pemilik-pemilik tanah apabila cukup nisabnya berdasarkan atas pendapatan bersih masing-masing setelah ditolak kos pengurusan projek yang dikeluarkan oleh agensi perlaksanaan. Namun, tidak semua negeri menerima pakai panduan taksiran zakat yang dikeluarkan oleh JAWHAR. Malah 
hanya negeri Kedah dan Perlis sahaja yang membenarkan kos pengeluaran pertanian dibenarkan ditolak daripada hasil kasar (Asmak Ab Rahman et. al, 2010).

\section{Pandangan Fuqaha' Tentang Kos Sara Hidup}

Syeikh Muhammad Arsyad al-Banjari (2008) turut tidak menjelaskan sama ada kos sara hidup dibenarkan ditolak daripada hasil pertanian tersebut. Namun apabila dirujuk kepada ayat al-Qur'an, zakat dikenakan ke atas lebihan kekayaan setelah memenuhi keperluan asas. Allah SWT berfirman yang bermaksud: "Dan mereka bertanya pula kepadamu: apakah yang mereka akan belanjakan (zakatkan)? Katakanlah: (infaq) yang berlebihan dari keperluan (kamu)'”(Surah al-Baqarah, 2:219).

Hal ini disokong oleh riwayat daripada Abu 'Ubayd bahawa Ibn 'Umar mengatakan kos sara hidup keluarga dibenarkan. Jabir Ibn Zaid meriwayatkan seperti berikut:

"Daripada Jabir Ibn Zaid, katanya: Dalam masalah seseorang yang berhutang dan kemudian membelanjakannya kepada keluarganya, kata Ibn 'Abas, dia perlu membayar apa-apa yang dia belanjakan untuk kebunnya sahaja. Kata Ibn 'Umar pula, dia perlu membayar apa yang dia belanjakan atas kebunnya dan juga kepada keluarganya" (Abu Ubayd, 1991).

Hal ini disokong dengan maksud zakat iaitu mengambil harta daripada golongan kaya untuk dikembalikan kepada golongan fakir miskin (al-Syawkani, 1996). Apatah lagi nafkah adalah tanggungjawab kepada ketua keluarga. Ia perlu diselesaikan terlebih dahulu sebelum membelanjakan bagi urusan lain. Perkara ini berdasarkan Hadis daripada Jabir bahawa Rasulullah SAW berkata yang bermaksud: "Berikanlah terlebih dahulu untuk kepentingan dirimu, apabila lebih berikanlah untuk isterimu, apabila masih lebih berikanlah kepada keluarga dekatmu apabila masih lebih berikanlah kepada yang lain-lain" (al-Nawawi, 1997).
Hal ini berbeza dengan taksiran zakat pendapatan di Malaysia. Bagi taksiran zakat pendapatan, kos sara hidup dibenarkan ditolak daripada pendapatan (JAKIM, 2008). Ia meliputi pertama, keperluan asasi, iaitu keperluan keluarga yang asas seperti perlindungan (rumah), makanan, pakaian dan seumpamanya. Kedua, belanjabelanja lain seperti keperluan diri sendiri, belanja isteri dan anak-anak, ibu bapa dan tanggungan lain seperti adik-beradik, anak angkat, orang gaji dan seumpamanya. Ketiga, simpanan di institusi yang telah membayar zakat. Zakat tidak dikenakan lebih daripada sekali terhadap sesuatu harta. Simpanan di Lembaga Tabung Haji (LTH) misalnya hendaklah ditolak daripada pendapatan. LTH telah membayar zakat bagi pihak penyimpan. Keempat, caruman wajib seperti caruman dalam KWSP turut dibenarkan ditolak. Caruman itu dibenarkan kerana pencarum tidak mempunyai milik sempurna ke atas caruman tersebut.

Namun, di Malaysia hanya negeri Perlis sahaja yang membenarkan kos sara hidup dibenarkan ditolak daripada hasil pertanian. Persoalannya, berdasarkan sumber daripada al-Qur'an, pendapat Ibn 'Umar, Hadis daripada Jabir dan amalan untuk taksiran zakat pendapatan, apakah wajar kos sara hidup untuk para petani tidak dibenarkan ditolak daripada hasil kasar? Pihak berkuasa di Malaysia sepatutnya telah lama menyelesaikan isu ini.

\section{Kesimpulan}

Berdasarkan keseluruhan perbincangan dalam artikel ini, dua kesimpulan dapat dibuat. Pertama, walaupun keadaan semasa dan keperluan setempat terpamer dalam kitab Sabil al-Muhtadin tulisan Syeikh Muhammad Arsyad al-Banjari itu, namun bagi taksiran hasil pertanian, ia terfokus kepada nisab dan kadar zakat padi. Ini mungkin itulah isu-isu kontemporari ketika kitab Sabil al-Muhtadin ditulis.

Kedua, taksiran zakat hasil pertanian perlu membenarkan kos pengeluaran ditolak 
disebabkan pertanian pada ketika ini lebih bersifat komersial. Sekiranya ia tidak dibenarkan, tidak mustahil terdapat para petani bertukar daripada pembayar zakat kepada penerima zakat khususnya semasa bencana alam melanda sawah mereka. Ini boleh menjadikan mereka golongan gharimin. Apatah lagi terdapat negeri yang membenarkan kos pengeluaran dan kos sara hidup ditolak daripada hasil kasar yang diperoleh.

\section{Penghargaan}

Kertas ini adalah sebahagian daripada dapatan kajian yang berjudul Perakaunan Zakat Pertanian Usahawan Tani di Malaysia (1001/ CISDEV/816218) yang dibiayai oleh Geran Universiti Penyelidikan (RUI), Universiti Sains Malaysia, Pulau Pinang, Malaysia.

\section{Rujukan}

Abu Ubayd, Q. S. (1991). Kitab al-Amwal (The Book Of Finance). Terjemahan Noor Mohammad Ghiffari. Pakistan Hijra Council, Islamabad.

Al-'Azim Abadi, A. M. (t.t). 'Awn al-Ma 'bud Syarh Sunan Abi Dawud, Jld. 4. Dar al-Kutub al-'Ilmiyyah, Beirut, Lubnan.

Al-Bukhari, M. I. (1996). Sahih Al-Bukhari. Terjemahan Muhammad Muhsin Khan. Maktaba Darussalam, Riyadh.

Al-Nawawi, M. Y. (1997). Sahih Muslim bi Syarh Imam al-Nawawi, Jld. 7. Dar al-Ma'rifah, Beirut, Lubnan:

Al-Syawkani, M. A. (1996). Nayl al-Awtar min Ahadith Sayyid al-Akhyar Sayrh Muntaqa alAkhbar, Jld. 4. Dar al-Khayr, Beirut, Lubnan.

Al-Zuhaili. W. (1994). Fiqh \& Perundangan Islam. Jld. III. Terjemahan Md. Khir Hj. Yaacob et al. Dewan Bahasa dan Pustaka, Kuala Lumpur.
Al-Qaradawi, Y. (1999). Terjemahan Monzer Kahf. Fiqh az-Zakat: A Comparative Study. Dar Al Taqwa Ltd, London.

Asmak, A. R., Pazim@Fadzim, O., Siti Mashitoh, M., Nor Aini, A, \& Azizi, C. S. (2010). Assessment Method for Agricultural Zakah in Malaysia: An Institutional Perspective. World Applied Sciences Journal 11(12):15001508 .

Ibn Hajar, A. H. (1989). Fath al-Bari Syarh Sahih al-Bukhari, Jld. 3. Dar al-Kutub al'Ilmiyyah, Beirut, Lubnan.

Ibn Hajar, A. A. (1992). Subul al-Salam Syarh Bulugh al-Maram min Jam' Adillah al-Ahkam, Jld. 2. Beirut. Maktabah al-'Asriyyah. Lubnan.

Jabatan Wakaf, Zakat dan Haji (JAWHAR). (2008). Manual Pengurusan Pengiraan Zakat. Jabatan Wakaf, Zakat dan Haji, Putrajaya.

Mahmood Zuhdi, A. M. (2003). Pengurusan Zakat. Dewan Bahasa dan Pustaka, Kuala Lumpur.

Mohd. Tamyes, A. W. (2002). Matlamat Seminar Fiqh Zakat Kontemporari”, kertas dasar yang dibentangkan di Seminar Fiqh Zakat 2002, anjuran Pusat Zakat Selangor, Petaling Jaya, 31 Oktober.

Mujaini, T. (1999). Zakat Pendapatan: Hukum dan Persoalannya. Khaisha Services, Kuala Lumpur.

Siddiqui, M. S. (1981). A Study of Evolution of Ijtihad (Legal Reasoning) in the Development of the Zakat Law During the $1{ }^{\text {st }}$ Century A.H. Tesis Ph.D. University of Edinburgh.

Syeikh Muhammad Arsyad al-Banjari. (2008). Kitab Sabil al-Muhtadin. Terjemahan MKA Kreatif Enterprise. Perniagaan Jahabersa, Johor Baharu.

Wan Mohd Shaghir, A. (2005). Syeikh 
Muhammad Arsyad al-Banjari pengarang Sabil al-Muhtadin. Utusan Malaysia, 25 September.

Wan Mohd Shaghir, A. (2009). Koleksi Ulama Nusantara, Jilid 2. Persatuan Pengkajian Khazanah Klasik Nusantara dan Khazanah Fathaniyah, Kuala Lumpur. 
